\title{
Drug Administrations for Patients Improves Hematologic Values in Fighting COVID-19 at Private Hospital in Jakarta, Indonesia
}

\author{
Ilham Arief
}

Clinical and Community Pharmacy, STIKes Widya Dharma Husada, Indonesia.

\begin{abstract}
No specific drugs have been found for the COVID-19 pandemic until now. The drug administration follows the national standards imposed to prevent the worsening of the patient's condition in the hope of recovery. The purpose of this study was to look at the effect of drug administration on hematologic parameters before and after the administration of drugs. This research method is cohort-based observational with the collection of retrospective medical record data from March to October 2020 at the Central Jakarta Private Hospital, Indonesia. The results showed improvement values in hematologic parameter values in eosinophils, neutrophils, monocytes, and neutrophil-lymphocyte ratios, and statistically, the parameter of eosinophils values is a significant difference after administering the drug.
\end{abstract}

Keywords: Drug Administrations; Hematologic Values; Fight COVID-19

\section{Introduction}

COVID-19 or Coronavirus disease is a disease caused by Severe acute respiratory syndrome coronavirus 2 (SARS-CoV-2)(Common-, 2003). This new disease and has spread rapidly from Wuhan (Hubei province) to other provinces in China and around the world including Jakarta, Indonesia (X. Yang et al., 2020). In mid-December was reported the first case of COVID-19 (Pormohammad et al., 2020), Where there are five patients with symptoms of fever, cough, and tightness accompanied by acute respiratory conditions, one in five of these patients died (Liu et al., 2020).

The virus can be transmitted from human to human and has spread in China and spread to 190 other countries and regions so on March 12, 2020, WHO declared a pandemic (Frater et al., 2020). So many people around the world are dead, especially in the United States and Europe. People are living differently, shopping differently, and thinking differently to fight this pandemic(Said Ambu Saidi et al., 2021). Moreover, The virus has mutated with new variants that have increased the rate and ease of transmission and reproduction. New variants and the roll-out of vaccinations have also altered the symptomatology experienced by patients(Thomson et al., 2021). Another way to prevention, the Indonesian government provides continued education on COVID-19 prevention with the $5 \mathrm{M}$ health protocol and the importance of multivitamins in the COVID-19 pandemic to increase immunity and reduce transmission rates(Aulia et al., 2021).

The treatment procedures given immediately to patients in hospital are currently not specific to COVID-19 but with the administration of these drugs can work the development of viruses, the administration of antibiotics to prevent secondary infections, the administration of vitamins and minerals for immune enhancement, and the administration of drugs with symptomatic to existing symptoms(Azer, 2020).

\section{Methods}

This is cohort-based analytical-observational research in which data was obtained retrospectively from the medical records of COVID-19 isolated patients between March and October 2020 at the Private Hospital Central of Jakarta. Subsequently, the data was organized and calculated statistically. The Wilcoxon sign tests were used to perform different analyses before and after drug administration, respectively.

The inclusion criteria comprised of patients over 12 years old with a confirmed COVID-19 diagnosis, with or without comorbidities, drug therapy, and clinical laboratory examinations. Meanwhile, the exclusion 
criteria included patients, who were transferred to the isolation treatment from another hospital, forced to return home or die, and those with incomplete hematologic laboratory data.

\section{Results And Discussion}

A total population of 373 patients was recruited, of which 225 met the inclusion and exclusion criteria. Also, the demographics of the subjects consisted of gender, age, and severity level.

\section{Patient Demographics}

Table 1 shows that the percentage of male and female patients in the research was $52.24 \%$ and $47.55 \%$, respectively. The age groups with the highest confirmed cases were 26-45 and 46-65 years, with values of $44.89 \%$ and $36.45 \%$, respectively. Moreover, males within the productive age gap have the highest risk of being exposed to the virus because they are more mobile and work outside the home. However, these subjects have better immunity and are more likely to recover (Cortis, 2020; Davies et al., 2020).

Table 1. Patient demographics

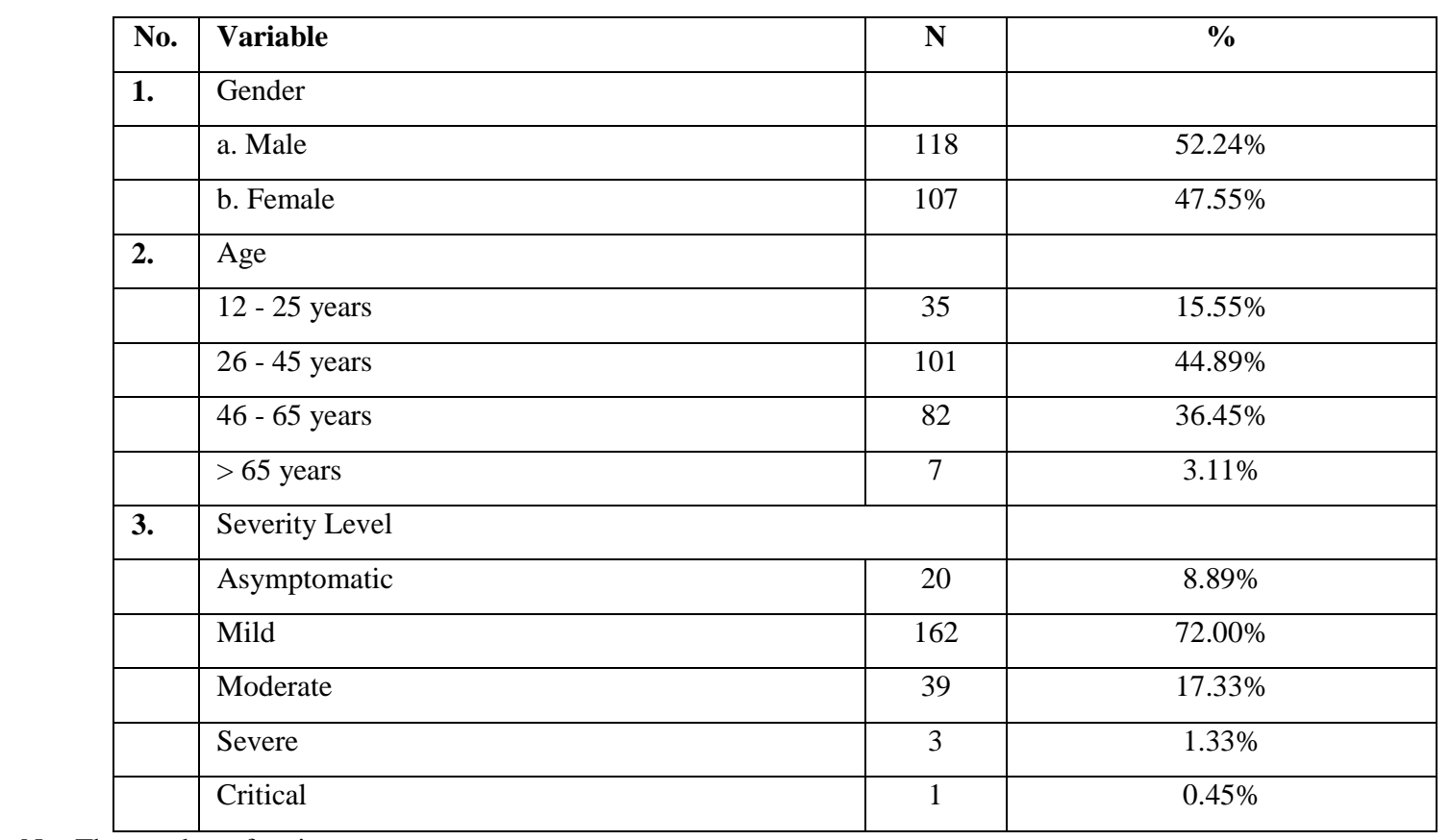

$\mathrm{N}=$ The number of patients.

\section{Clinical Symptoms and Comorbidity Diseases}

Table 2 displays the data of the highest clinical characteristics obtained from the medical records during hospital admission. According to the clinical symptom data obtained upon admission, 137 (61.19\%), 108 (48.01\%), $39(17.20 \%), 39(17.20 \%)$, and $37(16.31 \%)$ patients experienced symptoms of cough, fever, shortness of breath, anosmia, and sore throat, respectively. The virus mainly infects the respiratory system but may cause damage to the digestive system, urogenital system, central nervous system, and circulatory system(Zhang et al., 2020).

Cough is an effort to defend the lungs against various physiological stimuli and reflexes, hence protecting the organ from mechanical, chemical, and temperature trauma. This phenomenon becomes pathological when perceived as a nuisance. Also, cough is a disease sign that occurs within or outside the lungs and is occasionally an early symptom of infection (Azer, 2020). The SARS-CoV-2 virus binds to the ACE2 receptor and initiates inflammation in the lungs, which often results in hyperplasia and metaplasia of the mucosal cells as well as airway obstruction leading to persistent coughing(Qin et al., 2020).

Similarly, fever is a normal physiological response in the body due to a setpoint change in temperature regulation within the hypothalamus. These setpoint changes occur due to the binding of the SARS-CoV-2 virus to the ACE2 receptor. Subsequently, cytokines are induced to secrete TNF $\alpha$, IFN- $\gamma$, IL 1, IL 4, and IL 6 at the right level, which activates cellular and non-specific immunity(J. Yang et al., 2020). 
Table 2. Clinical symptoms of patients on hospital admission

\begin{tabular}{|l|l|c|c|}
\hline No. & Variable & $\mathrm{N}$ & $\%$ \\
\hline 1 & Cough & 137 & 61.19 \\
\hline 2 & Fever & 108 & 48.01 \\
\hline 3 & Shortness of breath & 39 & 17.20 \\
\hline 4 & Anosmia & 37 & 17.20 \\
\hline 5 & Sore throat & 31 & 16.31 \\
\hline 6 & Flu & 30 & 14.05 \\
\hline 7 & Nauseous & 13 & 13.58 \\
\hline 8 & Headache & 13 & 7.71 \\
\hline 9 & Ageusia & 17.91 \\
\hline 10 & Diarrhea & 30 & 5.91 \\
\hline
\end{tabular}

$\mathrm{N}=$ The number of patients.

Table 3 shows the most frequent comorbidities among the confirmed COVID-19 patients included 50 $(21.71 \%), 16(8.04 \%)$, and $17(7.29 \%)$ people with hypertension, dyspepsia, and diabetes mellitus, respectively.

Table 3. Patients comorbidities

\begin{tabular}{|l|r|r|}
\hline \multicolumn{1}{|c|}{ Comorbidity } & N & \% \\
\hline Hypertension & 50 & 21.71 \\
\hline Dyspepsia & 18 & 8.04 \\
\hline Diabetes Mellitus Type 2 & 17 & 7.29 \\
\hline Pneumonia & 16 & 6.89 \\
\hline Liver Disorder & 9 & 3.72 \\
\hline Dyslipidemia & 7 & 2.73 \\
\hline Asthma & 4 & 1.83 \\
\hline Kidney disorders & 4 & 1.83 \\
\hline Coronary heart disease & 2 & 0.91 \\
\hline Tuberculosis & 2 & 0.91 \\
\hline
\end{tabular}

Moreover, the major clinical characteristics symptoms in this research are fever and cough similar to other research. According to Huang Chaolin et al.(Huang et al., 2020), 40 (98\%), 31 (76\%), and 18 (44\%) people had a fever, cough, and myalgia, respectively. Also, research by Khamis et al. (Khamis et al., 2020) showed that fever $(84 \% ; n=53)$, cough $(75 \% ; n=47)$, and shortness of breath $(59 \% ; n=37)$ were the most common symptoms at the onset of the disease.

The binding of the SARS-CoV-2 virus to the ACE2 receptor reduces anti-inflammatory function and increases the amount of Angiotensin II which can raise blood pressure. Therefore, confirmed COVID-19 patients with hypertension have a greater risk of death than those without comorbidities (J. Yang et al., 2020).

\section{Drug Administrations}

COVID-19 as a new disease that has more than one clinical symptom upon hospital admission allows for many combinations of drug administrations(kemenkes RI, 2020). The combination of drugs in this study was grouped into 4 (four) large groups of drug administrations in COVID-19 patients, namely as in Table 4: 
Tabel 4. Groups of drug administrations in COVID-19 patients

\begin{tabular}{|c|l|c|c|}
\hline $\begin{array}{c}\text { Groups of Drugs } \\
\text { Administrations }\end{array}$ & \multicolumn{1}{|c|}{ Compositions } & N=225 & $\%$ \\
\hline 1 & $\begin{array}{l}\text { Antiviral, Antibiotics, Vitamin-Mineral \& } \\
\text { Symptomatic Therapy }\end{array}$ & 177 & 78.67 \\
\hline 2 & $\begin{array}{l}\text { Antiviral, Vitamin-Mineral \& Simptomatic } \\
\text { Teraphy }\end{array}$ & 27 & 12.00 \\
\hline 3 & $\begin{array}{l}\text { Antibiotics, Vitamin-Mineral \& Symptomatic } \\
\text { Therapy }\end{array}$ & 16 & 7.11 \\
\hline 4 & Vitamin-Mineral & 5 & 2.22 \\
\hline
\end{tabular}

$\mathrm{N}=$ The number of patients

In table 4. presented data on the use of the most used drug groups in group 1 (one) which has a combination composition of antiviral drugs, antibiotics, vitamins, and symptomatic therapy with 177 patients (78.67\%). The difference in the use of this drug combination is due to differences in the severity of the patient's clinical symptoms and treatment decisions from the medical team.

To determine the correlation between the drug administration groups and hematology parameters, a different test was performed before and after drug administrations. Data were obtained before and after administering the drug or before the patient was declared cured. However, the Wilcoxon test was used because the data had an abnormal distribution. The results are illustrated in Table 5 below:

Table 5. Wilcoxon test before and after drug treatment on hematology parameters

\begin{tabular}{|c|c|c|c|c|}
\hline Parameters & $\begin{array}{l}\text { Reference } \\
\text { Value }\end{array}$ & $\begin{array}{c}\text { Average } \\
\text { Before } \\
(\mathrm{N}=225)\end{array}$ & $\begin{array}{l}\text { Average After } \\
(\mathbf{N}=225)\end{array}$ & $\begin{array}{c}\mathbf{p} \\
\text { (Wilcoxon } \\
\text { Test) }\end{array}$ \\
\hline Hemoglobin (g/dl) & $12.5-17.5$ & $13.77 \pm 2.13$ & $12.96 \pm 2.05$ & 0.000 \\
\hline Hematocrit (\%) & $37-50$ & $40.90 \pm 5.68$ & $39.05 \pm 5.50$ & 0.001 \\
\hline $\begin{array}{l}\begin{array}{l}\text { Erythrocytes } \\
\text { (million/ } \mu \mathrm{L})\end{array} \\
\end{array}$ & $4.45-5.84$ & $5.00 \pm 0.74$ & $4.73 \pm 0.68$ & 0.000 \\
\hline MCV (fl) & $82-98$ & $82.45 \pm 7.33$ & $81.82 \pm 11.39$ & 0.362 \\
\hline $\mathrm{MCH}(\mathrm{pg})$ & $27-33$ & $27.64 \pm 27.62$ & $27.71 \pm 2.92$ & 0.647 \\
\hline MCHC (g/dL) & $32-36$ & $33.45 \pm 33.44$ & $33.25 \pm 1.37$ & 0.069 \\
\hline RDW (\%) & $11,5-14,5$ & $13.267 \pm 1.48$ & $13.40 \pm 1.58$ & 0.145 \\
\hline Platelets (thousand/ $\mu \mathrm{L}$ ) & $150-400$ & $253.69 \pm 104.06$ & $363.48 \pm 142.37$ & 0.000 \\
\hline $\begin{array}{l}\text { Leukocytes } \\
\text { (thousand } / \mu \mathrm{L} \text { ) }\end{array}$ & $5.0-10.0$ & $6.02 \pm 2.20$ & $7.12 \pm 2.94$ & 0.032 \\
\hline Basophils (\%) & $0.0-1.49$ & $0.31 \pm 0.17$ & $0.43 \pm 0.25$ & 0.003 \\
\hline Eosinophils (\%) & $1.5-4.49$ & $\mathbf{0 . 7 9} \pm 1.52$ & $2.19 \pm 1.50$ & 0.000 \\
\hline Neutrophils (\%) & $\begin{array}{l}49.5- \\
70.49\end{array}$ & $\mathbf{7 0 . 5 6} \pm 5.91$ & $62.76 \pm 5.77$ & 0.141 \\
\hline Lymphocytes (\%) & $20-40$ & $24.94 \pm 24.95$ & $26.00 \pm 7.99$ & 0.461 \\
\hline Monocytes (\%) & $2.0-9.0$ & $\mathbf{9 . 0 3} \pm 3.17$ & $8.64 \pm 2.49$ & 0.608 \\
\hline ESR $(\mathrm{mm})$ & $0-10.49$ & $\mathbf{3 4 . 8 1} \pm 27.48$ & $39.32 \pm 22.48$ & 0.406 \\
\hline NLR & $<3$ & $\mathbf{3 . 0 4} \pm 1.42$ & $2.95 \pm 2.16$ & 0.394 \\
\hline
\end{tabular}

$\mathrm{MCV}=$ Mean Corpuscular Volume, $\mathrm{MCH}=$ Mean Corpuscular Hemoglobin, MCHC $=$ Mean Corpuscular Hemoglobin Concentration, RDW= Red cell Distribution Width, ESR= Erythrocyte Sedimentation Rate, and NLR= Neutrophil-Lymphocyte Ratio.

Table 5 shows that eosinophils, neutrophils, monocytes, ESR, an NLR before drug administration is outside of range reference values and returned to normal after medication. Statistically, hemoglobin, hematocrit, erythrocytes, platelets, leukocytes, basophils, and eosinophils are the parameters with a p-value $<0.05$, hence there is a considerable difference before and after drug use. However, eosinophils displayed a more 
significant difference because before administering the drug, it was outside the reference value and then returned to normal after the medication.

These results indicate that the drug treatment improves the immune system of COVID-19 patients, which is indicated by a significant difference in the value of eosinophil hematology parameters same as Outh et.al study(Outh et al., 2021) Therefore, these medications are expected to suppress the development of the SARS-Cov-2 virus in the patient's body.

\section{Conclusion}

The different tests conducted before and after the drugs administrations on hematology parameters had a difference for eosinophil, neutrophils, monocytes, and neutrophil-lymphocyte ratios. Statistically, Eosinophils significant difference after administering the drug.

\section{References}

1. Aulia, G., Rahmah Fahriati, A., Okta Ratnaningtyas, T., Meitania Utami, S., Dwi Pratiwi, R., Adi Ismaya, N., Purnama Sari, F., Monja, T., Kania Rahsa Puji, L., \& Ayu Sabrina, P. (2021). Covid-19 Prevention Education With the Health Protocol of 5M and the Importance of Multivitamins During Covid-19 Pandemic. Jurnal Abdi Masyarakat, 2(1), 133-139.

2. Azer, S. A. (2020). COVID-19: pathophysiology, diagnosis, complications and investigational $\begin{array}{lllll}\text { therapeutics. New Microbes and New Infections, } & 37(\mathrm{M}), \quad 100738 .\end{array}$ https://doi.org/10.1016/j.nmni.2020.100738

3. Common-, V. (2003). SARS-Associated Coronavirus. N ENGL J MED, 348(20), 1948-1951.

4. Cortis, D. (2020). On Determining the Age Distribution of COVID-19 Pandemic. Frontiers in Public Health, 8(May), 1-3. https://doi.org/10.3389/fpubh.2020.00202

5. Davies, N. G., Klepac, P., Liu, Y., Prem, K., Jit, M., Pearson, C. A. B., Quilty, B. J., Kucharski, A. J., Gibbs, H., Clifford, S., Gimma, A., van Zandvoort, K., Munday, J. D., Diamond, C., Edmunds, W. J., Houben, R. M. G. J., Hellewell, J., Russell, T. W., Abbott, S., ... Eggo, R. M. (2020). Agedependent effects in the transmission and control of COVID-19 epidemics. Nature Medicine, 26(8), 1205-1211. https://doi.org/10.1038/s41591-020-0962-9

6. Frater, J. L., Zini, G., d'Onofrio, G., \& Rogers, H. J. (2020). COVID-19 and the clinical hematology laboratory. International Journal of Laboratory Hematology, 42(S1), 11-18. https://doi.org/10.1111/ijlh.13229

7. Huang, C., Wang, Y., Li, X., Ren, L., Zhao, J., Hu, Y., Zhang, L., Fan, G., Xu, J., Gu, X., Cheng, Z., Yu, T., Xia, J., Wei, Y., Wu, W., Xie, X., Yin, W., Li, H., Liu, M., .. Cao, B. (2020). Clinical features of patients infected with 2019 novel coronavirus in Wuhan, China. The Lancet, 395(10223), 497-506. https://doi.org/10.1016/S0140-6736(20)30183-5

8. kemenkes RI. (2020). Agustus 2020 PEDOMAN TATALAKSANA COVID-19. https://www.papdi.or.id/pdfs/938/Pedoman Tatalaksana COVID-19 edisi 2.pdf

9. Khamis, F., Al-Zakwani, I., Al Naamani, H., Al Lawati, S., Pandak, N., Omar, M. B., Al Bahrani, M., Bulushi, Z. AL, Al Khalili, H., Al Salmi, I., Al Ismaili, R., \& Al Awaidy, S. T. (2020). Clinical characteristics and outcomes of the first 63 adult patients hospitalized with COVID-19: An experience from Oman. Journal of Infection and Public Health, 13(7), 906-913. https://doi.org/10.1016/j.jiph.2020.06.002

10. Liu, J., Liu, Y., Xiang, P., Pu, L., Xiong, H., Li, C., Zhang, M., Tan, J., Xu, Y., Song, R., Song, M., Wang, L., Zhang, W., Han, B., Yang, L., Wang, X., Zhou, G., Zhang, T., Li, B., ... Wang, X. (2020). Neutrophil-to-lymphocyte ratio predicts critical illness patients with 2019 coronavirus disease in the early stage. Journal of Translational Medicine, 18(1). https://doi.org/10.1186/s12967-020-02374-0

11. Outh, R., Boutin, C., Gueudet, P., Suzuki, M., Saada, M., \& Aumaître, H. (2021). Eosinopenia $<100 / \mu \mathrm{L}$ as a marker of active COVID-19: An observational prospective study. Journal of Microbiology, Immunology and Infection, 54(1), 61-68. https://doi.org/10.1016/j.jmii.2020.12.005

12. Pormohammad, A., Ghorbani, S., Baradaran, B., Khatami, A., J. Turner, R., Mansournia, M. A., Kyriacou, D. N., Idrovo, J. P., \& Bahr, N. C. (2020). Clinical characteristics, laboratory findings, radiographic signs and outcomes of 61,742 patients with confirmed COVID-19 infection: A systematic review and meta-analysis. Microbial Pathogenesis, 147. 
https://doi.org/10.1016/j.micpath.2020.104390

13. Qin, C., Zhou, L., Hu, Z., Zhang, S., Yang, S., Tao, Y., Xie, C., Ma, K., Shang, K., Wang, W., \& Tian, D. S. (2020). Dysregulation of immune response in patients with coronavirus 2019 (COVID$19)$ in Wuhan, China. Clinical Infectious Diseases, 71(15), 762-768. https://doi.org/10.1093/cid/ciaa248

14. Said Ambu Saidi, K. S., Abu Kausar, M., \& M. Elshaiekh, N.-E. (2021). The Impact of COVID-19 on Economic of Oman and Omani Customer's Behaviour. International Journal of Scientific Research and Management, 9(07), 2266-2279. https://doi.org/10.18535/ijsrm/v9i07.em01

15. Thomson, M. E., Pollock, A. C., \& Murray, J. (2021). Composite Quantile Probability Predictions : Performance and Coherence Analysis of US COVID-19 Confirmed Infection Cases. 09(12), 471489. https://doi.org/10.18535/ijsrm/v9i12.mp01

16. Yang, J., Zheng, Y., Gou, X., Pu, K., Chen, Z., Guo, Q., Ji, R., Wang, H., Wang, Y., \& Zhou, Y. (2020). Prevalence of comorbidities and its effects in coronavirus disease 2019 patients: A systematic review and meta-analysis. International Journal of Infectious Diseases, 94(January), 9195. https://doi.org/10.1016/j.ijid.2020.03.017

17. Yang, X., Yu, Y., Xu, J., Shu, H., Xia, J., Liu, H., Wu, Y., Zhang, L., Yu, Z., Fang, M., Yu, T., Wang, Y., Pan, S., Zou, X., Yuan, S., \& Shang, Y. (2020). Clinical course and outcomes of critically ill patients with SARS-CoV-2 pneumonia in Wuhan, China: a single-centered, retrospective, observational study. The Lancet Respiratory Medicine, 8(5), 475-481. https://doi.org/10.1016/S2213-2600(20)30079-5

18. Zhang, Y., Geng, X., Tan, Y., Li, Q., Xu, C., Xu, J., Hao, L., Zeng, Z., Luo, X., Liu, F., \& Wang, H. (2020). New understanding of the damage of SARS-CoV-2 infection outside the respiratory system. $\begin{array}{llll}\text { Biomedicine and } & \text { Pharmacotherapy, } & 127 \text { (April), }\end{array}$ https://doi.org/10.1016/j.biopha.2020.110195

19. Aulia, G., Rahmah Fahriati, A., Okta Ratnaningtyas, T., Meitania Utami, S., Dwi Pratiwi, R., Adi Ismaya, N., Purnama Sari, F., Monja, T., Kania Rahsa Puji, L., \& Ayu Sabrina, P. (2021). Covid-19 Prevention Education With the Health Protocol of $5 \mathrm{M}$ and the Importance of Multivitamins During Covid-19 Pandemic. Jurnal Abdi Masyarakat, 2(1), 133-139.

20. Azer, S. A. (2020). COVID-19: pathophysiology, diagnosis, complications and investigational therapeutics. New Microbes and New Infections, 37(M), 100738. https://doi.org/10.1016/j.nmni.2020.100738

21. Common-, V. (2003). SARS-Associated Coronavirus. N ENGL J MED, 348(20), 1948-1951.

22. Cortis, D. (2020). On Determining the Age Distribution of COVID-19 Pandemic. Frontiers in Public Health, 8(May), 1-3. https://doi.org/10.3389/fpubh.2020.00202

23. Davies, N. G., Klepac, P., Liu, Y., Prem, K., Jit, M., Pearson, C. A. B., Quilty, B. J., Kucharski, A. J., Gibbs, H., Clifford, S., Gimma, A., van Zandvoort, K., Munday, J. D., Diamond, C., Edmunds, W. J., Houben, R. M. G. J., Hellewell, J., Russell, T. W., Abbott, S., ... Eggo, R. M. (2020). Agedependent effects in the transmission and control of COVID-19 epidemics. Nature Medicine, 26(8), 1205-1211. https://doi.org/10.1038/s41591-020-0962-9

24. Frater, J. L., Zini, G., d'Onofrio, G., \& Rogers, H. J. (2020). COVID-19 and the clinical hematology laboratory. International Journal of Laboratory Hematology, 42(S1), 11-18. https://doi.org/10.1111/ijlh.13229

25. Huang, C., Wang, Y., Li, X., Ren, L., Zhao, J., Hu, Y., Zhang, L., Fan, G., Xu, J., Gu, X., Cheng, Z., Yu, T., Xia, J., Wei, Y., Wu, W., Xie, X., Yin, W., Li, H., Liu, M., ... Cao, B. (2020). Clinical features of patients infected with 2019 novel coronavirus in Wuhan, China. The Lancet, 395(10223), 497-506. https://doi.org/10.1016/S0140-6736(20)30183-5

26. kemenkes RI. (2020). Agustus 2020 PEDOMAN TATALAKSANA COVID-19. https://www.papdi.or.id/pdfs/938/Pedoman Tatalaksana COVID-19 edisi 2.pdf

27. Khamis, F., Al-Zakwani, I., Al Naamani, H., Al Lawati, S., Pandak, N., Omar, M. B., Al Bahrani, M., Bulushi, Z. AL, Al Khalili, H., Al Salmi, I., Al Ismaili, R., \& Al Awaidy, S. T. (2020). Clinical characteristics and outcomes of the first 63 adult patients hospitalized with COVID-19: An experience from Oman. Journal of Infection and Public Health, 13(7), 906-913. https://doi.org/10.1016/j.jiph.2020.06.002

28. Liu, J., Liu, Y., Xiang, P., Pu, L., Xiong, H., Li, C., Zhang, M., Tan, J., Xu, Y., Song, R., Song, M., 
Wang, L., Zhang, W., Han, B., Yang, L., Wang, X., Zhou, G., Zhang, T., Li, B., ... Wang, X. (2020). Neutrophil-to-lymphocyte ratio predicts critical illness patients with 2019 coronavirus disease in the early stage. Journal of Translational Medicine, 18(1). https://doi.org/10.1186/s12967-020-02374-0

29. Outh, R., Boutin, C., Gueudet, P., Suzuki, M., Saada, M., \& Aumaître, H. (2021). Eosinopenia $<100 / \mu \mathrm{L}$ as a marker of active COVID-19: An observational prospective study. Journal of Microbiology, Immunology and Infection, 54(1), 61-68. https://doi.org/10.1016/j.jmii.2020.12.005

30. Pormohammad, A., Ghorbani, S., Baradaran, B., Khatami, A., J. Turner, R., Mansournia, M. A., Kyriacou, D. N., Idrovo, J. P., \& Bahr, N. C. (2020). Clinical characteristics, laboratory findings, radiographic signs and outcomes of 61,742 patients with confirmed COVID-19 infection: A systematic review and meta-analysis. Microbial Pathogenesis, 147. https://doi.org/10.1016/j.micpath.2020.104390

31. Qin, C., Zhou, L., Hu, Z., Zhang, S., Yang, S., Tao, Y., Xie, C., Ma, K., Shang, K., Wang, W., \& Tian, D. S. (2020). Dysregulation of immune response in patients with coronavirus 2019 (COVID$19)$ in Wuhan, China. Clinical Infectious Diseases, 71(15), 762-768. https://doi.org/10.1093/cid/ciaa248

32. Said Ambu Saidi, K. S., Abu Kausar, M., \& M. Elshaiekh, N.-E. (2021). The Impact of COVID-19 on Economic of Oman and Omani Customer's Behaviour. International Journal of Scientific Research and Management, 9(07), 2266-2279. https://doi.org/10.18535/ijsrm/v9i07.em01

33. Thomson, M. E., Pollock, A. C., \& Murray, J. (2021). Composite Quantile Probability Predictions : Performance and Coherence Analysis of US COVID-19 Confirmed Infection Cases. 09(12), 471489. https://doi.org/10.18535/ijsrm/v9i12.mp01

34. Yang, J., Zheng, Y., Gou, X., Pu, K., Chen, Z., Guo, Q., Ji, R., Wang, H., Wang, Y., \& Zhou, Y. (2020). Prevalence of comorbidities and its effects in coronavirus disease 2019 patients: A systematic review and meta-analysis. International Journal of Infectious Diseases, 94(January), 9195. https://doi.org/10.1016/j.ijid.2020.03.017

35. Yang, X., Yu, Y., Xu, J., Shu, H., Xia, J., Liu, H., Wu, Y., Zhang, L., Yu, Z., Fang, M., Yu, T., Wang, Y., Pan, S., Zou, X., Yuan, S., \& Shang, Y. (2020). Clinical course and outcomes of critically ill patients with SARS-CoV-2 pneumonia in Wuhan, China: a single-centered, retrospective, observational study. The Lancet Respiratory Medicine, 8(5), 475-481. https://doi.org/10.1016/S2213-2600(20)30079-5

36. Zhang, Y., Geng, X., Tan, Y., Li, Q., Xu, C., Xu, J., Hao, L., Zeng, Z., Luo, X., Liu, F., \& Wang, H. (2020). New understanding of the damage of SARS-CoV-2 infection outside the respiratory system. $\begin{array}{lll}\text { Biomedicine } \quad \text { and } & 110195 .\end{array}$ https://doi.org/10.1016/j.biopha.2020.110195 